\title{
Memory, Identity and Old Age: The Sense of an Ending as the Story of Ageing
}

Hafıza, Kimlik ve Yaşlılık: Yaşlanma Hikayesi Olarak Bir Son Duygusu

\author{
Çiğdem Alp Pamuk \\ Adnan Menderes University, Turkey
}

\begin{abstract}
The Sense of an Ending (2011) by Julian Barnes touches upon many issues such as gender, class, sexuality, death, and memory. It particularly underlines how our memories can be misleading and thus create false images of ourselves as well as of the people around us. One of the subjects dealt with in the novel is the process of ageing. Barnes does not represent the period of senescence as the phase of decay and stagnancy. Rather, it is a new stage in one's life when a new sense of the self is formed and new facets of life - either positive or negative - are (re)discovered. Beginning particularly with the 1970s, old people with complex and interesting personalities have become the focus of contemporary fiction. The increase in the number of elderly people, the developments in gerontology and the theories of ageing have contributed to the emergence of new literary genres such as midlife bildung, reifungsroman and vollendungsroman. The aim of this paper is to focus on the complexities of later life represented in The Sense of an Ending and analyse the novel considering the features of vollendungsroman, a term suggested by Constance Rooke to define "the novel of completion" or "winding up".
\end{abstract}

Keywords: Julian Barnes, The Sense of an Ending, Vollendungsroman, ageing, memory

Öz

Julian Barnes Bir Son Duygusu (2011) romanında, cinsiyet, sınıf, cinsellik, ölüm ve hafıza gibi pek çok konuya değinir. Özellikle, hafızamızın bizi nasıl yanıltabileceğine ve kendimiz ve etrafımızdaki insanlara dair nası sahte öz-imgeler oluşturabileceğimize dikkat çeker. Romanda ele alınan konulardan birisi de yaşlanma sürecidir. Barnes yaşlılık dönemini çürüme ve durgunluk evresi olarak değerlendirmez. Aksine bu dönemi, kişinin kendi benliğine dair yeni çlkarımlarda bulunduğu ve hayatın olumlu ya da olumsuz yeni yönlerinin keşfedildiği bir evre olarak değerlendirir. 1970'li yıllarla birlikte ilginç ve karmaşık kişiliğe sahip yaşlı karakterler çağdaş edebiyatın odak noktası olmuştur. Yaşlı nüfusun artması, gerontoloji alanındaki gelişmeler ve yaşlanmayla ilgili kuramlar midlife bildung, reifungsroman ve vollendungsroman gibi roman türlerinin ortaya çıkmasına katkıda bulunmuştur. Bu çalışmanın amacı, Bir Son Duygusu adlı eseri yaşlanma sürecine dair kuramlar çerçevesinde ele almak ve bu eserin eleştirmen Constance Rooke tarafından vollendungsroman (tamamlanma romanı) olarak adlandırılan roman türünün özelliklerini nasıl yansıttığını incelemektir.

Anahtar Kelimeler: Julian Barnes, Bir Son Duygusu, Vollendungsroman, yașlanma, hafiza

CUJHSS, December 2020; 14/2: 229-239. DOI: $10.47777 /$ cankujhss.848905

(C) Çankaya University ISSN 1309-6761 Printed in Ankara

Submitted: June 20, 2020; Accepted: Oct 28, 2020

ORCID\#: 0000-0002-0605-6182; cigdem.alp@hotmail.com 
Beginning with the 1970s, old people with riveting stories and interesting personalities have been foregrounded by the writers of contemporary fiction. The growing number of elderly people, gerontological studies and new theories on ageing have been influential in the appearance of literary genres centring on old people such as midlife bildung, reifungsroman and vollendungsroman. The vollendungsroman, a term which was proposed by the literary critic Constance Rooke in 1992, is known as the novel of completion or winding up. Rooke notes that "the task of the Vollendungsroman is to discover for its protagonist and the reader some kind of affirmation in the face of loss" (1992:248). The old people in these texts generally experience the feelings of loss and regret and know that death is an inevitable fact, but they appreciate life despite their past mistakes and decisions. The Sense of an Ending (2011), by the contemporary British writer Julian Barnes, may be evaluated as an example of vollendungsroman. The novel narrates the story of Antony Webster, a retired old man who receives an unexpected legacy from the mother of his exgirlfriend. While trying to solve the mystery of this strange inheritance, he journeys into the past through memories and confronts his self-image both in past and present times. Tony's journey changes his ideas about life and people. The Sense of an Ending is generally considered to be a novel about the disillusionment and regrets of an elderly person who feels sorry for his past life and hopeless for the future. However, it might be misleading to view the novel merely as the story of a despairing old man who is stuck in present time without the hope of change. Rather, the transformation of the protagonist together with his changing views on life suggest affirmation of life, which makes the novel an example of vollendungsroman. In the novel, the period of senescence is not represented as the phase of decline and stagnancy. Rather, it is rendered as a new stage in one's life when a new sense of the self is formed and new facets of life - either positive or negative - are (re)discovered. On the whole, The Sense of an Ending is a text in which the old protagonist transforms himself and gains new insights into life in spite of all his losses and mistakes.

The studies concerning old age often make a reference to Greek mythology narrating the story of Aurora, the goddess of the Dawn, and her mortal Trojan husband, Tithonus. According to this story, Aurora asks Zeus to make Tithonus immortal. Although Zeus grants him an eternal life, the signs of old age begin to affect the health and physical appearance of Tithonus because Aurora forgets to ask for eternal youthfulness. When he gets older, he cannot move his limbs and desires for death in despair. Aurora cannot stand it further and puts her husband in a room and leaves him, closing the door. There, in his chamber, Tithonus babbles forever using meaningless words (Hamilton 428). The myth of Tithonus corresponds with the modern ideas associating old age with "dependence, disease, failure and sin" (Kart and Kinney 2). Because of "[t]he secular, scientific, and individualist tendencies of modernity" which started in the sixteenth century, "[o]ld age was redefined as a problem to be solved by science and medicine. By mid-twentieth century, older people were moved to society's margins and defined primarily as patients or pensioners" (Cole 3). In her ground-breaking work, The Coming of Age, first published in 1970, French 
feminist writer and philosopher Simone de Beauvoir points to the negative attitudes towards older people. She writes: "The myths and the clichés put out by bourgeois thought aim at holding up the elderly people as someone who is different, as another being" (3). They are viewed as "walking corpses" rather than "human beings, with a human life behind them" (De Beauvoir 6).

Ageism, that is, "[p]rejudice toward the elderly" (Waxman 7), has been a prevalent problem of modern societies, and the increase in the number of older population has intensified the problems stemming from ageist ideas. However, beginning with the 1930s, particularly with the development of gerontology as an independent scientific discipline, the views concerning old age have been re-evaluated, and new perspectives have been offered for the welfare of the aged citizens. In the broadest sense, gerontology is "the study of old age and ageing" (Stuart-Hamilton 1). It tries to understand "what the process of ageing is and how to make it as enjoyable as possible" (Stuart-Hamilton 5). Thus, as De Beauvoir underlines, gerontology "does not inquire into the pathology of old age but into the ageing process itself" (23). In short, gerontology studies help to maintain positive attitudes to ageing.

One of the well-known theories of ageing is psychosocial life-stage theory, which was offered by the developmental psychologist Erik Erikson. According to Erikson, beginning with birth, a person passes through eight developmental stages and has to resolve the conflicts in each phase for a healthy personality. The eighth stage starts around sixty-five and ends at death. This is the stage of life review when the conflicts of lifetime are tried to be solved. If it is achieved, "the person attains a real sense of fulfilment" (Stuart-Hamilton 13). Erikson's theory underlines that "[h]uman development and learning are lifelong processes and not restricted to childhood and adolescence" and that "[a]ging is not a one-dimensional process of decline; gains are possible even in older age" (Lipsky and Wernher 481).

Erikson's life-stage theory is in sharp contrast to the disengagement theory of Elaine Cumming and Warren Earl Henry. They argue that "a natural feature of ageing was to prepare for death by gradually withdrawing from society" (Stuart-Hamilton 14). So, they view the period of old age as the withdrawal from social interaction. For them,

[T] he process of disengagement was both inevitable and universal. All social systems, if they were to maintain successful equilibrium, would necessarily disengage from the elderly. Disengagement was seen as a prerequisite to social stability. Older people could be released from societal expectations that they work and be productive. Presumably, they would adapt by participating in satisfying family relationships and friendships. (Kart and Kinney 215)

Thus, the disengagement theory expects the involvement of the aged people not in social but in domestic life.

The theories of ageing, developed mainly with gerontological studies, are various, and they have changed the ideas on aging and old people. The 
changing attitudes towards the aged are noticeable in the field of literature as well. Contemporary authors have directed their attention to the engrossing life stories of older people. In her article "Literary Portrayals of Ageing," Diane Wallace underlines that "[t]he development of humanistic gerontology can be closely linked to the emergence in the early 1970s of a body of new fiction which self-consciously interrogated the process of ageing" (393). For her, this is a very important development because "[a]rtistic representations of older people have the potential to counter our ideas about age and ageing" (389). Many examples of contemporary fiction challenge the views associating old age with decline and loss. As the literary critic, Thomas R. Cole, argues "many contemporary writers of mid-life and late-life fiction ... are not preoccupied with loss and decline. Rather, they are giving expression to growing cultural impulses to explore the experiences of aging, to move toward something as one grows older - a unity of understanding; loving relations with others; the return of wonder; acceptance of mortality; God" (4). Recent fiction, he writes, "feature[s] older people as complex and exciting protagonists" (4). The same point is highlighted by Constance Rooke. In her article "Old Age in Contemporary Fiction: A New Paradigm of Hope," she highlights that "old people are now regarded by the writers of fiction as interesting; increasingly; they are now assigned major roles" (243).

Beginning chiefly with the 1970s, new literary genres focusing on the elderly people such as midlife progress novel, reifungsroman and vollendungsroman emerged. The first of these genres, midlife bildung (midlife progress novel), deals with adult life and represents the midlife period as a time of "recovery and development" (Gullette xii) rather than a phase of decline. Reifungsroman, the term suggested by Barbara Frey Waxman, focuses mostly on the female experiences of aging. The examples of this genre "defy the outmoded social expectation of passive senescence by taking charge of their lives, making changes, and traveling - inward, backward, forward into fuller, more intense lives and richer, philosophical deaths" (Waxman 183). The last of these genres, also the focus of this paper, is vollendungsroman suggested by Constance Rooke. Rooke argues that while bildungsroman concentrates on "the first phase of the life cycle (childhood and youth) as a preparation for life in society," vollendungsroman brings the last phase (old age) to the foreground (1992:245). It is the period of disengagement when the elderly people leave the social stage. According to Rooke, the two genres do not contradict each other. Rather, they are complementary and can be studied together because "[b]oth are concerned with basic identity themes, with the relationship of the individual to society, with an assessment of what living well means, and with the question of what comes next" (1992: 245).

The Sense of an Ending may be considered an example of vollendungsroman. Rooke highlights that the mission of the protagonist in these novels is to find ways to affirm life in spite of losses. Such a discovery can be possible with the deconstruction of ego. It is emphasized that "the task of our first life phase is sometimes given as the construction of ego ... The task of old age may be given as the deconstruction of ego, which may in some instances be translated as a 
willingness to let go of social power" (1992: 245). Although disengagement from active life is viewed as a negative phenomenon in the contemporary world, it actually has some advantages as it helps the formation of identity from a new perspective. She writes: "it remains a possibility that disengagement will benefit the old. If we shift our gaze, to regard that singular achieved ego as ... a failure ... then disengagement or the deconstruction of ego will seem vital" (1992: 247). In other words, disengagement provides the reconsideration and re-construction of the previously falsely-constructed ego. ${ }^{1}$

The protagonist and the narrator of the novel, Tony Webster, undergoes such a change. In his sixties, he discovers that the ego he has constructed throughout his life has to be reconsidered. The letter from a solicitor informing him of an inheritance from his ex-girlfriend's mother, Sarah Ford, forces him to review his past life. He inherits from Mrs. Ford five hundred pounds and the diary of Adrian, a high-school friend from whom he separated on account of the love affair between Adrian and his ex-girlfriend, Veronica. Tony wonders why Veronica's mother wanted him to possess the diary of Adrian, who died years ago as he committed suicide. To solve the mystery, Tony contacts Veronica, and she involuntarily transmits him a letter he wrote to Adrian years ago. It is a letter in which Tony curses the relationship between Adrian and Veronica. In response to Adrian's letter asking him if he approves of this relationship, Tony thinks he wrote a postcard to congratulate the couple. However, what he really did was to spill his hatred against them. After addressing Veronica as "Bitch," Tony continues his letter as follows:

Well you certainly deserve one another and I wish you much joy. I hope you get so involved that the mutual damage will be permanent. I hope you regret the day I introduced you. And I hope that when you break up ... you are left with a lifetime of bitterness that will poison your subsequent relationships. Part of me hopes you'll have a child, because I'm a great believer in time's revenge, yea unto the next generation and the next. See Great Art. But revenge must be on the right people, i.e. you two (and you're not great art, just a cartoonist's doodle). So I don't wish you that. It would be unjust to inflict on some innocent foetus the prospect of discovering that it was the fruit of your loins, if you'll excuse the poeticism. So keep rolling the Durex onto his spindly cock, Veronica. Or perhaps you haven't let him go that far yet? (95-96)

Reading that bitter and spiteful letter makes a tremendous effect on Tony. The letter shakes the self-image of Tony as a controlled and mature person. Up to that point, he is represented as a man who is satisfied with his routine and solitary life: "[b]y now I was used to my own routines, and fond of my solitude,"

\footnotetext{
${ }^{1}$ To point to the positive aspects of disengagement, Rooke gives the example of Shakespeare's King Lear. When King Lear decides to retire and loses his kingdom to his evil daughters, he starts to understand the real essence of his existence in the universe. He grows spiritually only after he is stripped of the power stemming from his active life as a king. His metamorphosis into a humane person becomes possible through the deconstruction of ego (1992:247).
} 
(55). He feels secure as he owns a "flat with possessions" and "a few drinking pals" and some "platonic" women friends (55). He abstains from questioning life and taking risks, and calls this "an instinct for survival, for selfpreservation" (42). The letter, however, teaches him that life is uncontrollable and surprising:

I reread this letter several times. I could scarcely deny its authorship or its ugliness. All I could plead was that I had been its author then, but was not its author now. Indeed, I didn't recognize that part of myself from which the letter came. But perhaps this was simply further selfdeception ... My younger self had come back to shock my older self with what that self had been, or was, or was sometimes capable of being. (98-99)

In his memories, he was a man who maturely coped with the pain caused by the affair between Veronica and Adrian. He thought he wished them good luck and then preferred to concentrate on his own life: he got married with Margaret and had a daughter, Susie. However, upon reading that letter, he starts questioning his self-image he has created in his lifetime.

One of the common structural devices of vollendungsroman is life review. "The protagonist is located within a present time frame ... and then through memory the character is transported into past time, often through a narrative voice that assesses past experiences in a new light. Thus, memory is important because it gives the reader (and the character) access to the past, and because it is being shaped by the character in the present" (Rooke 1992: 253). Based on the gerontologist Robert Butler's well-known article "The Life Review: An Interpretation of Reminiscence in the Aged with Psychological Dysfunction," Rooke argues that life review includes "a vital concern with the possibility of change (1988: 39). In this essay, Butler expresses his views concerning life review and memory. For him, life review accompanied by memories has some positive functions. The re-evaluation of the past experiences may give meaning to a person's present life. He writes: "As the past marches in review, it is surveyed, observed, and reflected upon by the ego. Reconsideration of previous experiences and their meanings occurs, often with concomitant revised or expanded understanding. Such reorganization of past experience may provide a more valid picture, giving new and significant meanings to one's life" (68). Thus, in the examples of vollendungsroman, life review helps the protagonist revise his past life and enhances his vision of the present. This is necessary for self-discovery, though this newly-discovered self is also subject to change. ${ }^{2}$

2 This point accords with Constance Rooke's views on the subject of identity in the examples of vollendungsroman. In most cases, she says, life is not "regarded as a finished work of art" (1992: 251). Rooke notes that "only rarely does a text conclude with a ringing endorsement of what the developmental psychologist Erik Erikson refers to as the old person's 'one and only life"' (1992: 250). The characters of vollendungsroman are subject to change even in the last minute, and this turns the novel into an unfinished artwork: "new meanings are constructed even as the ego or life of the individual is deconstructed" (Rooke 1992: 248). 
Life review has a central place in The Sense of an Ending. The old Tony journeys into the past through his memories, meets young Tony there, and reevaluates him in a new light. Similarly, young Tony influences the old one. This is actually a double-edged process which continually transforms one's identity. Tony lives in the present, but gives shape to his existing identity by choosing and evaluating his past memories. The elderly protagonist in the vollendungsroman, according to Rooke, "is often cast as a person looking back on (or reading) the 'story' that he or she has written and continues to write in life. In selecting, shaping, and evaluating the data of memory, the protagonist ... creates ... a sense of identity" (1993: 209). While evaluating his memories, Tony goes on to write his own story and tries to create a sense of identity.

Tony's problematic relationship with Veronica exemplifies this double-edged process, too. He met Veronica while he was studying history at Bristol. It was the 1960s when dating meant very close friendship, mostly without sex. Tony describes it as follows:

Back in 'my day' ... this is what used to happen: you met a girl, you were attracted to her, you tried to ingratiate yourself, you would invite her to a couple of social events ... then ask her out on her own, then again, and after a goodnight kiss of variable heat, you were somehow, officially, 'going out' with her. Only when you were semi-publicly committed did you discover what her sexual policy might be. And sometimes this meant her body would be as tightly guarded as a fisheries exclusion zone. (22)

Tony remembers Veronica just like the other girls of the period who took their lovers' arm in public, kissed them and pressed their breasts as long as "there were about five layers of clothing between flesh and flesh" (22). They avoided "full sex" (22). According to young Tony, the relationship between him and Veronica was not a love affair. It just made him proud to learn the details of female world: "about make-up, clothes policy, the feminine razor, and the mystery and consequences of a woman's periods" (27). When Veronica asks the prospect of their relationship, he claims that it does not "have to head somewhere" (34). They have sex only after they break up, and Tony understands that he does not want to continue this relationship anymore. Veronica accuses him of being a "selfish bastard" (37).

When Tony reviews his life to solve the mystery of Adrian's diary and tries to understand Veronica's present aloofness from him, he gets to know himself and the people around him better. Life review helps him explain his conflicts which remained unresolved in the past. Veronica, in his eyes, was a manipulative and selfish woman who started to date with Adrian as soon as they separated: "she is someone who will manipulate your inner self while holding hers back from you," (96) Tony warns Adrian in the letter. According to Tony, she was unable "to imagine anyone else's feelings or emotional life" (96). However, the ending of the novel underscores that, contrary to Tony's views, Veronica is an understanding and compassionate woman who takes care of his mentally-ill brother, the son of Adrian with her mother. Tony, on the 
other hand, fails in understanding the tragedies of her life until his discovery that the mentally-ill person is the son of Adrian and Sarah Ford. ${ }^{3}$

In her analysis of Margaret Laurence's novel, The Stone Angel, Constance Rooke evaluates the recognition of mistakes in old age as one of the features of vollendungsroman. She writes: "In general, we honour characters for their admirable behavior ... or, if they have misbehaved, for proof that they have changed or reformed. In Hagar's case, which is typical of many elderly characters in contemporary fiction, time has nearly run out; although she comes to a partial recognition of her mistakes, she cannot rectify them. Instead, she makes the gestures of atonement" (250). This is the case with Tony Webster. When he understands that the disabled man is actually the son of Adrian with Sarah Ford, rather than with Veronica, he feels really sorry. "I knew I couldn't change, or mend, anything now," (149) thinks Tony. He knows he cannot change anything now, but his vision of the self as well as of Veronica has changed with this information. In other words, the inner journey ends with the transformation of identity. Tony, at the end of the novel, is not the same person with Tony represented at the beginning of the novel. He is now a more understanding and mature person. Tony loses Veronica forever, as she rejects contacting with him due to his lack of understanding concerning the essence of the events. Yet this loss makes self-discovery possible. This loss makes him a more mature person who cares for other people's feelings. For the first time in his life, for example, he wonders what happened to the baby of Robson, a high school friend who committed suicide when he learnt the pregnancy of his girlfriend: "I found myself wanting, even at this distance, to apologise to Robson's girl for the idle way we had discussed her, without reckoning her pain and shame" (141), he thinks.

Affirmation of life despite mistakes is one of the most common themes in the examples of Vollendungsroman. Rooke notes that "it is sometimes too late for these characters to act or change their lives in ongoing and externally verifiable ways" (1992: 251). Yet, the characters affirm life in spite of the error of their ways. What Rooke means by affirmation is the idea that "there is value in human life and cause for celebration" (1992: 250). Affirmation of life is usually not pronounced directly. Rather, the readers sense that there is hope for future generations to fulfill their potential (Rooke 1992: 251). The aged people feel regretful for their mistakes and know that it is not easy to rectify them. Yet, the novels in general imply affirmation of life and nourish the hope that dreams are a part of life although they cannot be actualized.

On the surface, The Sense of an Ending does not suggest hope or a ground for celebration. At the end of the novel, for instance, Tony comments on the

\footnotetext{
3 The continual construction and deconstruction of the self as well as the silences in the text make it difficult to solve the mystery concerning the identity of the disabled person. Some critics argue that he is the son of Tony and Sarah Ford; therefore, Tony invents an alternative false story to avoid the pain of this traumatic experience. See "Deceptive Re-narration and Self-Justifying Narrative in Julian Barnes's The Sense of an Ending" by Nazila Heidarzadegan and Ömer Tüm.
} 
impossibility of change towards the end of life: "You get towards the end of life - no, not life itself, but of something else: the end of any likelihood of change in that life" (149). These statements suggest stagnancy and immobility rather than transformation and change. Besides, the final lines of the novel imply uneasiness and discontentment. Julian Barnes writes: "There is accumulation. There is responsibility. And beyond these, there is unrest. There is great unrest" (150). According to the critic Dóra Vecsernyés, these final comments point to the hopeless situation of Tony Webster, who is stuck in present time without hope for the future. She writes: "This desperate state of feeling guilt, remorse and confusion is squeezed into the confines of the present simple tense, illustrating Tony's state of being locked up in the present without any prospect for future improvement or possibility of altering the past" (39-40). Even though the final remarks of Tony about life signify stagnancy, his character change throughout the novel contradicts this seemingly hopeless state of mind. Moreover, while musing over his feelings for Veronica, Tony himself underlines that life is full of surprises. He says: "Eventually I said to myself: Right, so you're feeling guilt towards your ex-wife, who divorced you twenty years ago, and excitement towards an old girlfriend you haven't seen in forty years. Who said there were no surprises left in life?" (118). Tony's statements underscore that life has the capacity to puzzle the elderly people because life is uncontrollable, surprising, and it cannot be estimated.

The images used in the novel also signal the value of life and its transformative power. Constance Rooke notes that there are some images commonly used in the vollendungsroman, and the two of them are the house and water. The house, she writes, can be viewed as

a 'time capsule' that protects the elderly inhabitant from the judgmental, frighteningly changed outside world. And it is a shelter against the "outside" forces of nature, so in this way it becomes symbolically a barrier or a stay against death. In part because we regard ourselves as 'living in' the body, the house is essentially an image of the body; and the dilapidation or disorder of the house is often used to signal the body's decline. (Rooke 1992:255)

So, the house may be considered to be symbolizing the body of the aged person. In line with this view, Tony's efforts to keep the house in order may be evaluated as a defying act against death. His tidiness signifies his desire to keep the body healthy and alive.

The less time there remains in your life, the less you want to waste it. That's logical, isn't it? Though how you use the saved-up hours - well, that's another thing you probably wouldn't have predicted in youth. For instance, I spend a lot of time clearing things up - and I'm not even a messy person. But it's one of the modest satisfactions of age. I aim for tidiness; I recycle; I clean and decorate my flat to keep up its value. I've made up my will; and my dealings with my daughter, son-in-law, grandchildren and ex-wife are, if less than perfect, at least settled. Or so I've persuaded myself. I've achieved a state of peacefulness. Because I 
get on with things. I don't like mess, and I don't like leaving a mess. I've opted for cremation, if you want to know. (68)

With these lines, Tony is actually affirming the value of life as an elderly person. He knows that death is inevitable, and he wants to prolong life by keeping his body healthy, which is symbolically explained by the neatness of his flat.

Another image signifying the transformative force of life is the water. Water, "in its formlessness and mobility is often opposed to the firmness of the house" (Rooke 1992:255). It "is associated with the fear of death and the hope of spiritual renewal ... typically, the aged protagonist moves away from the particular house and toward the universal water" (Rooke 1993: 222). The Sense of an Ending begins and ends with images which are related to water. The novel opens with Tony's memories all of which are linked with water imagery: "steam rising from a wet sink," "gouts of sperm circling a plughole," "a river rushing nonsensically upstream," "another river, broad and grey," and "bathwater long gone cold behind a locked door" (3). As the plot unfolds, the connection between these images and the events of the plot is understood. The image of cold bathwater, for example, is a reference to Adrian's death as he cuts his wrists in the bath. The novel ends with the image of Tony in his house thinking of "a crescent wave of water, lit by a moon, rushing past and vanishing upstream pursued by a band of yelping students whose torchbeams crisscrossed in the dark" (150). This is the memory of a scene from his university years when he went to see the Severn Bore with his friends. The Severn Bore is a large wave moving in the opposite direction of the river. The view of the wave moving upstream may be read as Tony's desire to travel back in time to change the past. He knows that real life is moving in one direction, towards death. Yet, he desires for a renewal by travelling in time to his past years.

In conclusion, the Vollendungsroman as a genre about old age period has some common characteristics: the use of life review as a structural device, deconstruction of the ego, recognition of mistakes, and affirmation of life in the face of loss. In The Sense of an Ending, life review has a central place because Tony's journey into past time and his reconsideration of past experiences give new meanings to his present life. By reviewing his life through memories, Tony repeatedly constructs and deconstructs his own identity and self-image. Tony's travel in time through memories makes him recognize his mistakes and feel regretful, but still he affirms life in spite of his erroneous experiences. Throughout the novel, there are pessimistic passages about the unlikelihood of change in the old age period. However, Tony's transformation from a selfish man into a compassionate person points to the transformative power of life. With the character of Tony, Julian Barnes focuses on the complexities of old age and ageing. In The Sense of an Ending, the senescent period is not depicted as the phase of failure and immobility. Rather, it is represented as a new stage suggesting change and transformation. 


\section{Works Cited}

Barnes, Julian. The Sense of an Ending. Vintage, 2011.

Butler, Robert N. "The Life Review: An Interpretation of Reminiscence in the Aged," Psychiatry, vol. 26, no. 1, 1963. pp. 65-76

Cole, T.R. "Introduction." The Oxford Book of Aging, edited by Thomas R. Cole and Mary G. Winkler. Oxford University Press, 1994.

De Beauvoir, Simone. The Coming of Age. Translated by Patrick O’Brien. G.P. Putnam's Sons, 1972.

Gullette, Margaret M. Safe at Last in the Middle Years the Invention of the Midlife Progress Novel: Saul Bellow, Margaret Drabble, Anne Tyler, and John Updike. University of California Press, 1988.

Hamilton, Edith. Mythology. Back Bay Books, 1998.

Heidarzadegan, N., and Tüm Ö. "Deceptive Re-narration and Self-Justifying Narrative in Julian Barnes' The Sense of an Ending," Journal of Narrative and Language Studies, vol. 7, no. 13, 2019. pp. 152-161.

Kart, Cary S. and Jennifer M. Kinney. The Realities of Aging: An Introduction to Gerontology. Allyn and Bacon, 2001.

Lipsky, Martin S. and Wernher Iris. "Psychological Theories of Aging," Disease-aMonth, vol. 61, no. 11, November 2015. pp. 480-488.

Rooke, Constance. "Old Age in Contemporary Fiction: A New Paradigm of Hope." Handbook of the Humanities and Aging. Edited by Thomas R. Cole, David D. Van Tassel, Robert Kastenbaum. Springer Publishing Company, 1992. pp. 241-257.

---. "Hagar's Old Age: The Stone Angel as Vollendungsroman." Crossing the River: Essays in Honour of Margaret Laurence, edited by Kristjana Gunnars. Winnipeg. Turnstone Press, 1988.

---. "Oh What a Paradise It Seems: John Cheever's Swan Song." Aging and Gender in Literature: Studies in Creativity, edited by Anne M. Wyatt-Brown and Janice Rossen. University Press of Virginia, 1993.

Stuart-Hamilton, Ian. An Introduction to Gerontology. Cambridge University Press, 2011.

Vecsernyés, Dóra. "With His Watch on the Inside of the Wrist: Time in Julian Barnes's The Sense of an Ending." Stunned into Uncertainty: Essays on Julian Barnes, edited by Eszter Tory and Janina Vesztergom. Eötvös Lóránd University, 2014.

Wallace, Diane. "Literary Portrayals of Ageing." An Introduction to Gerontology, edited by Ian Stuart-Hamilton. Cambridge University Press, 2011.

Waxman, Barbara F. From the Hearth to the Open Road: A Feminist Study of Aging in Contemporary Literature. Greenwood Press, 1990. 